\author{
Associate Professor Hong Xie, PhD \\ Zhejiang Gongshang University Hangzhou, China \\ E-mail: rockor@126.com \\ Yifei Cai, PhD Candidate, \\ The University of Western Australia, Australia \\ E-mail: caiyf736@nenu.edu.cn \\ Chung Yan Sam, PhD Candidate \\ University of Malaysia, Malaysia \\ E-mail: cysam1010@gmail.com \\ Professor Tsangyao Chang, PhD \\ Feng Chia University, TAIWAN and \\ Hubei University of Economics, CHINA \\ E-mail: tychang@mail.fcu.edu.tw
}

\title{
REVISIT FINANCIAL DEVELOPMENT, TRADE OPENNESS AND ECONOMIC GROWTH NEXUS IN CHINA USING A NEW DEVELOPED BOOTSTRAP ARDL TEST
}

\begin{abstract}
We revisit the causal links among financial development, trade openness and economic growth in China using a newly developed Bootstrap ARDL test over the period of 1978-2015. Empirical results indicate no long-run relationship among these three variables and Granger causality test based on ARDL model indicates a feedback between trade openness and economic growth and between trade openness and financial development and a one-way Granger causality running from financial development supporting supply-leading hypothesis. By looking at the sign of coefficients of the independent variable that we find both financial development and trade openness promote economic growth and economic growth further reduce trade openness. These empirical results have important policy implications for the government conducting both financial development and trade openness strategies to promote economic growth in China and financial development strategy is the most important one. Apparently our results support the supply-leading hypothesis in China.

Keywords: Financial Development; Trade Openness; Economic Growth; Bootstrap ARDL Test; China
\end{abstract}

JEL Classification: C22; O40; F10; F65

\section{Introduction}

Overall the past several decades, studies have been devoted to investigate what are the major determinants of economic growth in both the developing countries and

DOI: $10.24818 / 18423264 / 52.4 .18 .09$ 
advanced countries. For example, studies such as Menyah et al. (2014), all demonstrate that financial development is a major determinant of economic development in one country, supporting financial-led growth hypothesis. On the other hand, Krugman (1990) showed that international trade liberalization was good for economic growth in developing countries. Bhagwati and Srinivasan (2001) and Chang (2002) and Chang and Caudil (2005) also showed empirical evidence of the positive effect on economic growth.

This study contributes to current studies by investigating whether financial development and/or trade openness leads to economic growth or vice versa, using ADRL models with bootstrap method, for the centrally planned economy of Mainland China over the period 1978 to 2015. Mainland China provides an interesting arena to research for several reasons. First China has some typical features of economic growth and has made remarkable economic progress over the last few decades with an annual average economic growth rate of 7-9\% in the past two decades (1990 - 2015). Second, China's economy has become the second largest only next to the USA around the world since 2015. The overall economics in China in terms of total GDP will be sooner or later over pass that of the United States. Third, Mainland China has become the world's eleventh largest trading country with a foreign exchange reserve estimated at US\$ 3.12 trillion at the end of 2016. Fourth, Mainland China started its open policy in the late 1970s, thus sufficient data are available for researchers to evaluate the effect of economic liberalization on economic phenomena.

The remainder of this paper is organized as follows. Section II briefly describes previous literature. Section III presents the data used. Section IV describes the methodology used and the empirical findings and some policy implication are presented at Section V. Finally, Section IV concludes.

\section{Review of Literature}

Studies about the relationship between economic growth, financial development and trade liberalization are widely conducted over decades. These studies cover countries based on level of income, cross-country and regional comparison, and specific economy analysis. Generally, the literature concludes that the financial development and trade liberalization are key factors that help to foster the economic growth. Theoretically speaking, financial system helps to allocating the financial resources and financial development improves the size and efficiency of distribution of the resources. Economic is growth when a country has efficient financial system, especially for developing countries. A well-developed financial system encourages investment, funding in business opportunities, mobilizes savings, manage risks. These functions benefit the economic and thus foster its growth. (see Beck, 2002). For trade openness, Smith (1776) formalizes concepts and explains how trade can help to benefits between countries and thus, improve economic growth. Ricardo (1817) generalized Smith's views in his Principles of Political Economy and Taxation and come out a comparative advantage models. Theory states that for two countries, they can engage in mutually beneficial trade 
Revisit Financial Development, Trade Openness and Economic Growth Nexus in China Using a New Developed Bootstrap ARDL Test

with each other as well as promote productivity and specialize the production of goods of a country through technological progress, increased international and domestic competition. Many empirical studies supporting these financial lead growth or trade lead growth hypotheses, see Chang (2002) and Chang and Caudil (2005).

It seems that, generally, we agree that financial development and trade openness help to promote economic growth. However, in recent literature, there are scholars against this expectation and stated financial development and trade openness may not necessary help economic growth. Ozdemir (2014) mention that the increase of financial mobility causes speculative short-term capital movement, thus leads to macroeconomic instability and financial crisis. He further states that financial liberalization makes finance susceptible to shocks and thus fragility. This can turn bank and liquidity run. Influential economists such as Robinson (1952) do not agree that financial development is important in contributing economic growth. As oppose to this, they think that the relationship between financial and economic development is over-stressed and financial development is simply follows economic development. It shows that the relationship between financial development, trade openness and economic growth does not come to a consensus. Nevertheless, different conclusion may be resulted due to different methodologies, estimating variables and sample period.

When come to economic performance, China always attracted lots of attentions from economists and policy makers as China has achieved significant growth and social progress since economic reformation declared in 1978 under Deng Xiaoping's regime. Since the introduction of open-door policy, significant transformation is speculated rapid growth in the economic with an average 9\% real growth rate for more than two decades. This makes China claims its position to be one of the most influential economies in the world. The question whether China's rapid growth mainly due to its openness economic is then concerned. Over the years, number of economists and policy makers are interested to find out do financial development and trade openness are the main factors that drive China evolution. Chen (2008) studies the interaction of economic openness and institutional development on economic growth in China and he uses growth model based from Levine and Renelt (1992) and Mankiw et al. (1992) cover period from 1983 to 2001 and measured by GMM estimator. From the results, he concludes that economic openness giving positive impact on economic growth. Since the recent introduction of One Belt One Road policy from Chinese government, Zhang et al. (2017) study the impacts of trade liberalization brought from the policy on economic growth. By considering Computable General Equilibrium (CGE) model covering 17 sectors of industries, they conclude trade liberalization giving positive impact to economic growth as well, given that international payment balanced needed to be kept. Other than single equation estimation, Sakyi et al. (2015) use cross-sectional estimation employing non-stationary heterogeneous panel cointegration and Granger-causality test, by grouping China into upper-middle 
income, again, they conclude that trade liberalization gives positive effect to level of income and thus, economic growth. Hye et al. (2016)'s finding shows mixed results. They consider approaches such as ARDL cointegration test and rolling window regression to investigate these variables relationship in China using data 1975 to 2009. The results from ARDL test suggests that trade openness giving positive impact to the economic growth both in long-run and short-run but rolling window regression opposes the finding from ARDL by suggesting a negative impact.

In this study, we revisit the relationship between financial development, trade openness and economic growth by bootstrap ARDL test for cointegration. Bootstrap method on ARDL test is introduced by McNown et al. (2018). This approach is known to have advantages over Pesaran et al. (2001)'s ARDL bounds testing approach. Instead of using the critical values provided by Pesaran et al. (2001), critical values are bootstrapped and used for hypothesis testing. This test has shown to have excellent estimation power with good size and power properties. Besides, by augmenting an additional test on lagged independent variable(s), we can rule out the restriction on dependent variable to be I(1). As long as the testing variables' integration order do not exceed one, this bootstrap ARDL test is applicable. A clear cointegration status can be revealed by incorporating the additional test on lagged independent variable together with the existing tests from ARDL test, i.e. no-cointegration, cointegrated or degenerate cases. Moreover, the existing flaw of inconclusive estimation from ARDL bounds test is fixed from bootstrap. Bootstrap method helps to generate the exact properties from the given time series and thus, giving exact critical values. Decisive conclusion can be made from using the bootstrap critical values.

\section{Data}

We apply annual data covering the period from 1978 to 2015 for China. The variables used in this study include the nominal Gross Domestic Product (GDP), Financial development (FD) and it is measured as the ratio of (M2/GDP) and trade openness (OPD) and it is measured as ratio of (Exports and Imports)/GDP). GDP, Exports and Imports are retrieved from National Bureau of Statistics of China. Table 1 reports the summary statistics for the data series. From this Table 1 that we can see that both exports and imports combined together are about one third of GDP. Figure 1 and 2 show time series plots of these three variables. We find that both financial development and GDP variables are trending upwards and trade openness show a downturn after 2006 and grower slower than both financial development and GDP. Jarque-Bera statistics indicate that GDP variable is nonnormally distributed and both financial development and trade openness are normally distributed. 
Revisit Financial Development, Trade Openness and Economic Growth Nexus in China Using a New Developed Bootstrap ARDL Test

\section{Table 1: Data description}

\begin{tabular}{|c|c|c|c|c|c|c|c|}
\hline Variable & Mean & Median & Maximum & Minimum & Skewness & Kurtosis & $\begin{array}{c}\text { Jarque- } \\
\text { Bera (P- } \\
\text { value) }\end{array}$ \\
\hline GDP & 157622.9 & 75764.30 & 689052.1 & 3678.7 & 1.399 & 3.710 & $13.202 * *$ \\
\hline $\begin{array}{l}\text { Financial } \\
\text { Development }\end{array}$ & 0.674795 & 0.683587 & 1.438679 & 0.081455 & 0.077154 & 1.798604 & 2.323011 \\
\hline $\begin{array}{l}\text { Degree of } \\
\text { Openness }\end{array}$ & 0.351348 & 0.337178 & 0.642431 & 0.096501 & 0.142531 & 2.293938 & 0.917990 \\
\hline
\end{tabular}

$* * *, * *$ and $*$ indicate significance at the $1 \%, 5 \%, 10 \%$ levels, respectively.

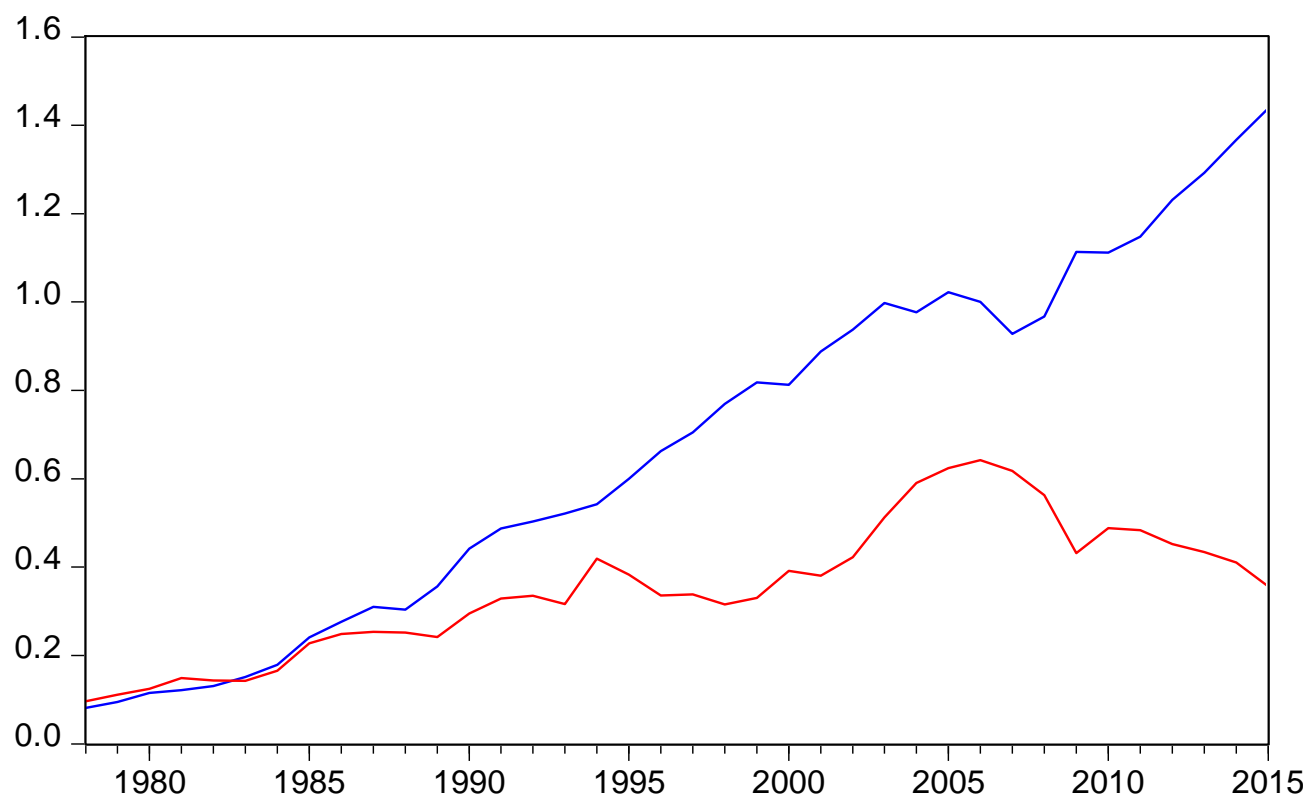

Figure 1. Plots of Financial Development and Degree of Openness - China $-\mathrm{FD}-\mathrm{OPD}$ 


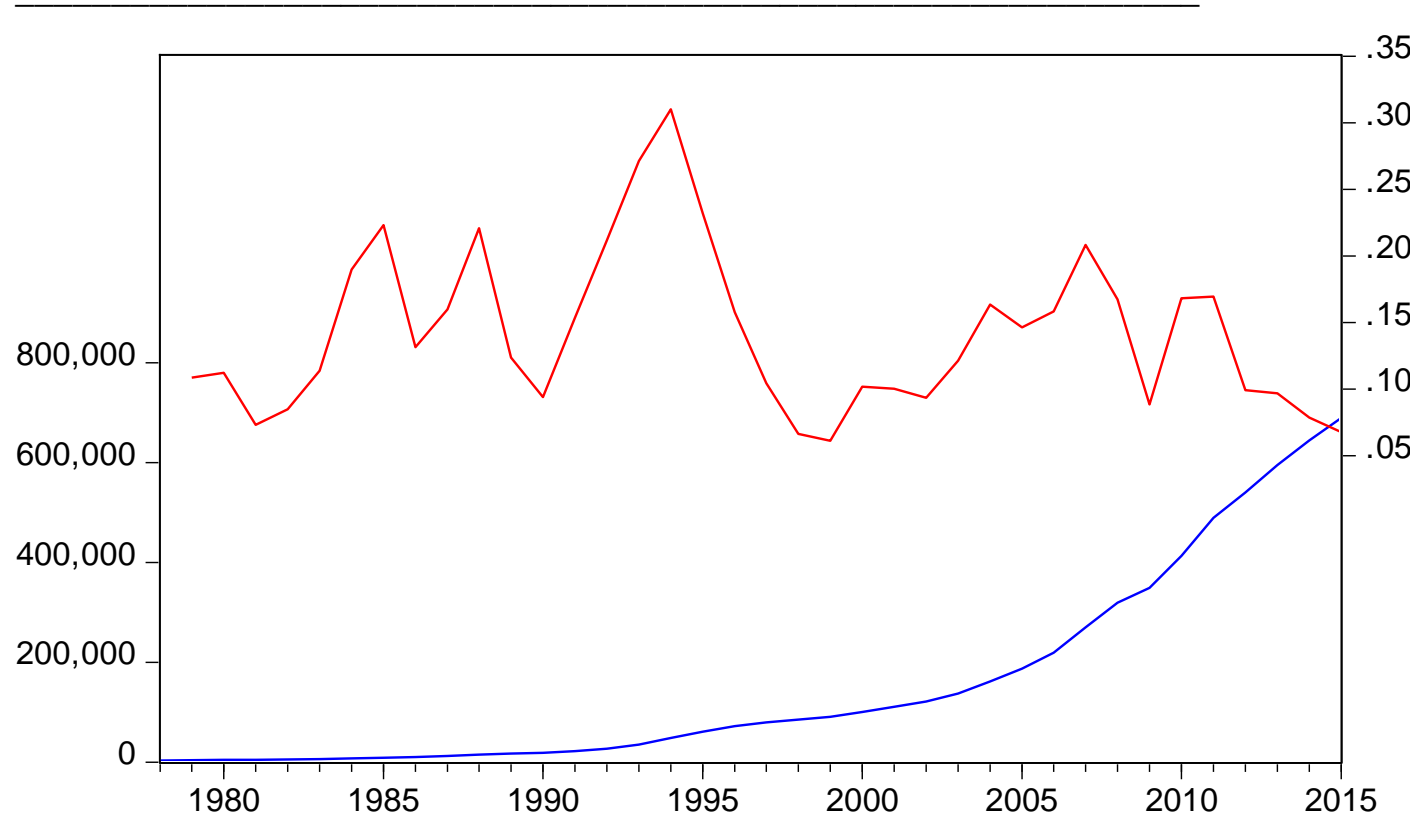

Figure 2. Plot of GDP and Economic Growth in China

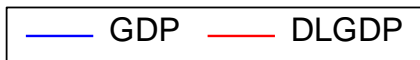

\section{Methodology}

4.1 ARDL Bound Tests (Pesaran et al., 2001; McNown et al., 2018)

Based on Pesaran et al. (2001) that we can write our ARDL model as the follows:

$\Delta Y_{t}=c+\alpha Y_{t-1}+\beta X_{t-1}+\sum_{i=1}^{p-1} \theta \Delta Y_{t-i}+\sum_{i=1}^{p-1} \delta X_{t-i}+\sum_{j=1}^{q} \eta_{j} D_{t, j}+\varepsilon_{t}$

and equation [1] requires no feedback from $\mathrm{Y}$ to $\mathrm{X}$. This means that we cannot allow two or more variables to be (weakly) endogenous and this violates the assumptions underlying the distributions of the test statistics presented by Pesaran et al. (2001). It assumes weak exogeneity of the regressors. These regressors are not impacted by the dependent variable in the long-run, but this does not preclude the existence of cointegratings among the regressions, nor does it assume the absence of (short run) Granger causality from the dependent variable to the regression. A lot of researchers from previous studies ignore this assumption in the empirical implications of the ARDL bounds test. However, and fortunately, McNown et al. (2018) shown that the endogeneity property has minor effect on the ARDL bounds test. According to Pesaran et al. (2001), cointegration test requires F-test or t-test for testing the following hypothesis: 
Revisit Financial Development, Trade Openness and Economic Growth Nexus in China Using a New Developed Bootstrap ARDL Test

$$
H_{0}: \alpha=\beta=0 \text { or } H_{0}: \alpha=0
$$

McNown et al. (2018) suggest that by adding an additional t-test to complement the existing $\mathrm{F}$ and t-tests for cointegration proposed by Pesaran et al. (2001). The use of all three tests is necessary to distinguish between cases of cointegration, noncointegration and degenerate cases defined by Pesaran et al. (2001). Note that degenerate cases are not cointegration. Degenerate cases happen when the any lagged dependent or lagged independent variable(s) found to be insignificant making an incomplete error adjustment from error correction term. Based on McNown et al. (2018) that we can define the two degenerate cases as the follows:

Degenerate case \#1 occurs when the F-test and the t-test on the lagged independent variable are significant, but the t-test on the lagged dependent variable is insignificant.

Degenerate case \#2 occurs when the F-test and the t-test on the lagged dependent are significant, but the lagged independent variables are not significant.

Pesaran et al. (2001) present critical values for case \#2, but not for case \#1. To rule out degenerate case \#1, the integration order for the dependent variable must be I(1). However, unit root tests are notorious for having low-power (Perron, 1989). The Bootstrap ARDL test tackles this problem through additional test on the coefficients of the lagged independent variables. The critical values for the test is generated from bootstrap procedures. The advantage of Bootstrap ARDL test inherited this benefit from Pesaran et al. (2001)'s bounds test with improved size and power properties. In addition, these generated bootstrap critical values have the additional advantage of eliminating the possibility of inconclusive inferences. Finally, McNown et al. (2018) also present an extension of the ARDL testing framework for the alternative degenerate case, with critical values generated by the bootstrap procedure. Therefore, the proposed Bootstrap ARDL test provides a better insight on the cointegration status of the series in the model.

\subsection{Granger Causality Test based on Bootstrap ARDL Model}

The direction of the short-run causal relationship will be determined by standard Granger-causality tests. If no cointegration is found between $\mathrm{y}$ and $\mathrm{x}$ when $\mathrm{y}$ is the dependent variable, then the Granger causality test for $\mathrm{x}=>\mathrm{y}$ should include the lagged differences on $\mathrm{x}$ only, that is, we test whether . However, if cointegration exists among the variables, then this means the dependent and the independent variables form a stationary linear combination. As a result, the lagged levels can be treated as $\mathrm{I}(0)$. In this case, the Granger-causality test for $\mathrm{x}=>\mathrm{y}$ should include the lagged differences on $\mathrm{x}$ and the lagged level of $\mathrm{x}$, i.e. test whether and . Of course that we can also extend the equation [1] to 3-variable case, see the following model: 


$$
\begin{aligned}
& \Delta Y_{t}=c+\alpha Y_{t-1}+\beta X_{t-1}+\gamma Z_{t-1}+\sum_{i=1}^{p-1} \theta_{i} \Delta Y_{t-i}+\sum_{i=1}^{p-1} \delta_{i} \Delta X_{t-i}+ \\
& \sum_{i=1}^{p-1} \omega_{i} Z_{t-i}+\sum_{j=1}^{q} \eta_{j} D_{t, j}+\varepsilon_{t}
\end{aligned}
$$

In this case, the Granger-causality test for $\mathrm{x}=>\mathrm{y}$ should include the lagged differences on $\mathrm{x}$ and the lagged level of $\mathrm{x}$, i.e. test whether and . For $\mathrm{z}=>\mathrm{y}$ should include the lagged differences on $\mathrm{z}$ and the lagged level of $\mathrm{z}$, i.e. test whether and (if they are cointegrated).

\section{Empirical Results and Policy Implications}

In this study, we employ Bootstrap ARDL test of cointegration technique advanced by McNown et al., (2018) to test for long-run relationship between GDP, financial development and trade openness in China over 1988-2015. The cointegration approach based with ARDL framework has several interesting characteristics. First, it performs better to small samples compared to alternative multivariate cointegration procedures (Romilly et al., 2001). Second, it does not require the restrictive assumption that all series are integrated of the same order allowing for the inclusion of both and (but not ) time series in a long-run relationship; the latter provides flexibility and also avoids potential "pre-test bias", that means, the specification of a long-run model on the basis of I(1) variables only (Pesaran et al., 2001).

\subsection{Results from the Unit Root Test}

Because the Bootstrap ARDL Test approach does not require the restrictive assumption that all series are integrated of the same order, thus allowing for the inclusion of both and time series in a long-run relationship, however, the presence of variables turns the computed statistic invalid (Pesaran et al., 2001). Therefore, we need to first go for several conventional unit root tests such as the ADF, PP (Phillips and Perron, 1988), and KPSS (Kwiatkowski et al, 1992). Table 2 reports the results from several conventional unit root tests which all suggest that these three variables employed are all non-stationary in levels, while they turn stationary in first differences. 
Revisit Financial Development, Trade Openness and Economic Growth Nexus in China Using a New Developed Bootstrap ARDL Test

\section{Table 2: Univariate unit root tests.}

\begin{tabular}{|c|c|c|c|c|c|c|}
\hline & \multicolumn{3}{|c|}{ Level } & \multicolumn{3}{|c|}{ First differences } \\
\hline & ADF & PP & KPSS & ADF & PP & KPSS \\
\hline GDP & $\begin{array}{l}-1.802661 \\
{[3]}\end{array}$ & $\begin{array}{l}2.492698 \\
{[3]}\end{array}$ & $\begin{array}{l}0.187750[3] \\
* *\end{array}$ & $-2.630995[5]$ & $-2.701096[4]$ & $\begin{array}{l}0.165341[4] \\
* *\end{array}$ \\
\hline $\begin{array}{l}\text { Financial } \\
\text { Developme } \\
\text { nt }\end{array}$ & $\begin{array}{l}-2.253273 \\
{[0]}\end{array}$ & $\begin{array}{l}-2.253273 \\
{[0]}\end{array}$ & $0.066451[3]$ & $\begin{array}{l}- \\
\text { 5.163327[0]* } \\
* *\end{array}$ & $\begin{array}{l}- \\
5.114125[2] * \\
* *\end{array}$ & $0.171869[1]$ \\
\hline $\begin{array}{l}\text { Degree of } \\
\text { Openness }\end{array}$ & $\begin{array}{l}- \\
1.744222[ \\
0]\end{array}$ & $\begin{array}{l}- \\
1.755601[ \\
2]\end{array}$ & $\begin{array}{l}0.604003[5] \\
* *\end{array}$ & $\begin{array}{l}-4.596471[0] \\
* * *\end{array}$ & $\begin{array}{l}-4.582663[2] \\
* * *\end{array}$ & $0.264592[2]$ \\
\hline
\end{tabular}

Notes: ***, ** and * indicate the null hypothesis is rejected at the $1 \%, 5 \%$ and $10 \%$ levels, respectively. The number in brackets indicates the lag order selected based on Schwarz information criterion. The number in the parenthesis indicates the truncation for the Bartlett Kernel, as suggested by the Newey-West test (1987).

\subsection{Results from Bootstrap ARDL Test - Cointegration Test}

Because we have established that all variables are integrated of one or zero (or $\mathrm{I}(1)$ and $\mathrm{I}(0)$ ), we proceed to test for cointegration by employing the Bootstrap ARDL test approach. The selection of the optimal Bootstrap ARDL specifications is selected based on the Schwarz information Criterion which is asymptotically consistent for the lag length and is favoured by Pesaran and Shin (1999). The selection of the optimal nonlinear ARDL specifications, is based on a general-tospecific approach, starting with and dropping all the insignificant lags using a 5\% decision rule. The statistics of the Bootstrap ARDL approach being reported in Table 3 indicate strong evidence in favour of the non-existence of a long-run cointegrating relationship among GDP, financial development and trade openness in China. Therefore, we proceed to test the Granger causality test based on our Bootstrap ARDL model in difference. 
Hong Xie, Yifei Cai, Chung Yan Sam, Tsangyao Chang

Table 3. Cointegration Results using Bootstrap ARDL Bound Test

\begin{tabular}{|c|c|c|c|c|c|c|c|c|c|}
\hline Variable & DV|IV & $\begin{array}{l}\text { Dummy } \\
\text { variables }\end{array}$ & $\mathbf{F}$ & $\mathbf{F}^{*}$ & $\mathbf{T}_{\text {dep }}$ & $\mathbf{T *}$ dep & $\mathbf{F}_{\text {indep }}$ & $\mathbf{F}^{*}$ indep & Result \\
\hline GDP & $\begin{array}{l}\text { GDP| } \\
\text { FD, } \\
\text { OPD }\end{array}$ & $\mathrm{d} 00 \mathrm{~d} 10$ & 3.940 & 13.588 & $\begin{array}{l}- \\
1.932\end{array}$ & $\begin{array}{l}- \\
2.679\end{array}$ & 4.537 & 5.191 & $\begin{array}{l}\text { No- } \\
\text { cointegration }\end{array}$ \\
\hline $\begin{array}{l}\text { Financial } \\
\text { Development }\end{array}$ & $\begin{array}{l}\text { FD | } \\
\text { GDP, } \\
\text { OPD }\end{array}$ & $\begin{array}{l}\text { d90 d98 } \\
\text { d09 }\end{array}$ & 12.147 & 12.621 & $\begin{array}{l}- \\
1.164\end{array}$ & $\begin{array}{l}- \\
1.614\end{array}$ & 3.329 & 17.825 & $\begin{array}{l}\text { No- } \\
\text { cointegration }\end{array}$ \\
\hline $\begin{array}{l}\text { Degree of } \\
\text { Openness }\end{array}$ & $\begin{array}{l}\text { OPD | } \\
\text { GDP, } \\
\text { FD }\end{array}$ & $\begin{array}{l}\text { d85 d91 } \\
\text { d03 d09 }\end{array}$ & 1.652 & 3.495 & $\begin{array}{l}- \\
2.369\end{array}$ & $9^{1.53}$ & 2.198 & 4.2581 .2 & $\begin{array}{l}\text { No- } \\
\text { cointegration }\end{array}$ \\
\hline
\end{tabular}

Notes: [.] is optimal lag order based on Akaike Information Criterion (AIC). F is the F-statistic for the coefficients of $y t-1, x t-1$ and $\mathrm{zt}-1$; Tdep denotes the t-statistics for the dependent variable, Tindep denotes the $t$-statistics for the independent variable. $F^{*}, T_{-}$dep and $T$ _indep are the critical values at $5 \%$ significance level, generated from the bootstrap program. Dummy variables are to capture any economics shocks. D00 means 1 for year 2000, other years are 0 .

\subsection{Granger Causality Test Results based on Bootstrap ARDL Model and Policy Implications}

Table 4 reports Granger causality test results based on Bootstrap ARDL model. From Table 4 we can see that a feedback exist between GDP and trade openness and between financial development and trade openness. We also find a one-way Granger causality running from financial development to economic growth (GDP). Apparently we can see that both economic growth (GDP) and trade openness and financial development and trade openness reinforce each other in China. If we look at the sign of all coefficients of all independent variables and we find out that both financial development and trade openness are important determinants of economic growth (GDP) because we find both financial development and trade openness significantly affect economic growth (GDP) in China. This means that both trade and financial sectors are important sectors for conducting economic development in China. On the other hand, we find that economic growth (GDP) harms trade openness and trade openness promotes both economic growth (GDP) and financial development during this time period in China. Financial sector development also promotes trade openness and these two variables reinforce each other during the economic development in China. Figure 3 demonstrates the causal relationship among these three variables (i.e., Economic growth (GDP), financial development and trade openness). 
Revisit Financial Development, Trade Openness and Economic Growth Nexus in China Using a New Developed Bootstrap ARDL Test

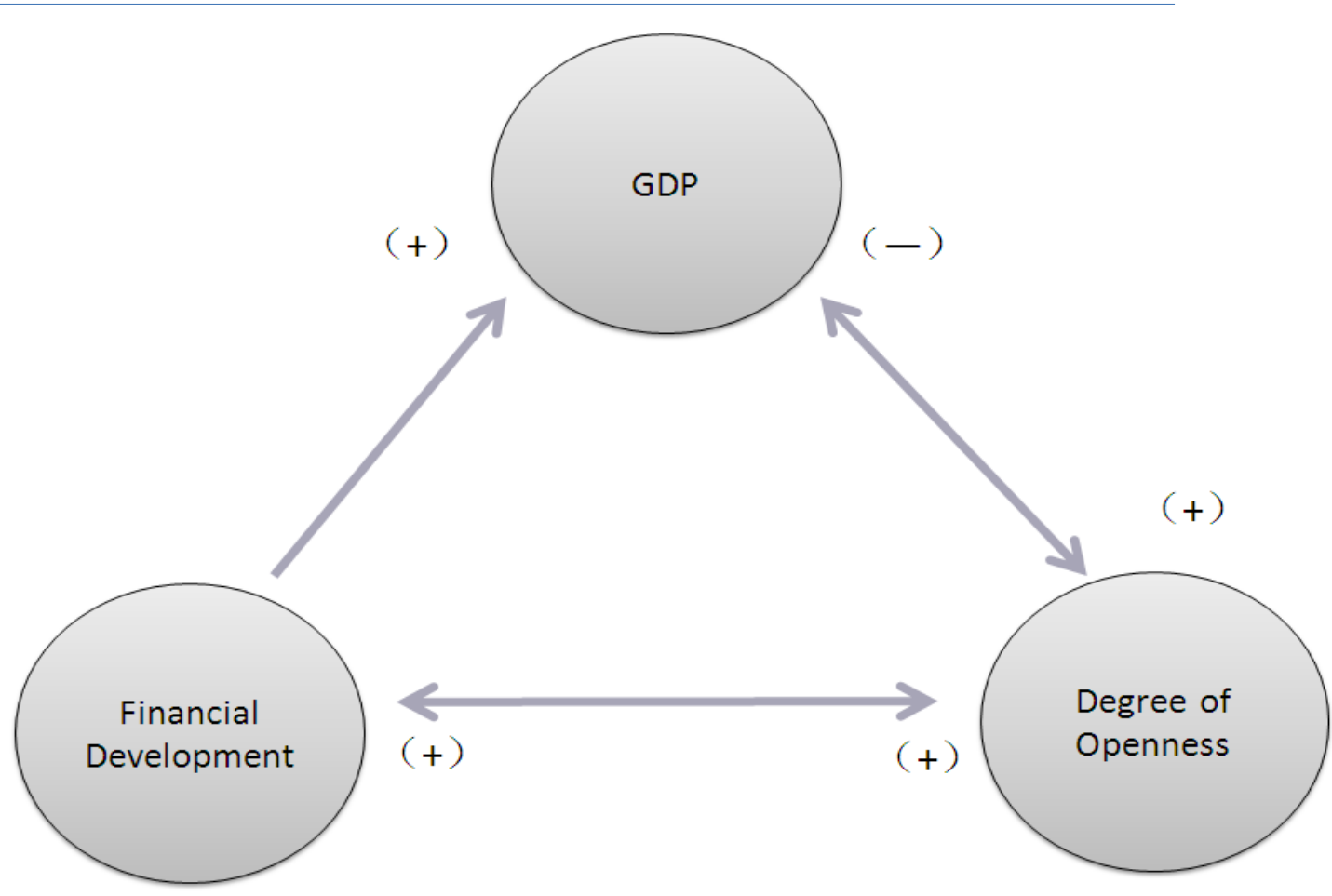

Figure 3. Causal Link among GDP, Financial Development and Trade Openness

This figure further confirms our empirical findings. Apparently our empirical findings support the supply-leading hypothesis and economic growth affects financial development indirect through the trade openness. Therefore, China should continue to patronize the development of its financial sector and to allow more trade openness in order to achieve a high and sustainable economic growth. These results are not consistent with those of Chang (2002) for China supporting neither the supply-leading nor the demand-following hypothesis. Our results are not consistent with that of Ayeche et al. (2016) supporting a feedback between financial development and economic growth for 40 European countries and Turkey, respectively, but also not consistent with those of Rehman et al. (2015) and Saaed and Hussain (2015) supporting a demand-following or growthled finance hypothesis for Saudi Arabia and Kuwait, respectively. However, our results are consistent with that of Menyah et al. (2014) supporting financial-led growth hypothesis. Regarding trade openness and economic growth that we find these two variables reinforce each other and this empirical finding indicates that trade sector is an important sector for economic development, however economic development further reduces (and or slow down) trade openness in China. 
Apparently, our empirical result is consistent with those of Bhagwati and Srinivasan (2001), Chang (2002), Chang and Caudil (2005) shown a strong positive relationship between openness of the economy and growth. However, our result is not consistent with those of Barboza and Trejos (2008) showed that openness of the economy does not lead to economic growth and Kim et al. (2012) showed that international trade causes economic growth in high income, low inflation, and nonagricultural economies but had a negative impact on economic growth in countries with opposite attributes. However, why economic growth in China lead to a reduction in trade openness might be due to three reasons: First of all, constantly adjust economic structure in China causes industrial system to continue make significant improve, thereby reducing the dependence of the external economy. Secondly, in order to protect the domestic just start-up industries and thus the government in China adopted some restrictions on import policy. Thirdly, due to the continuous development of China's economy, the other trading partners constitute a certain threat, and thus by the trade of other countries to resist, all these leading to China's trade openness getting lower. In sum, our empirical results have important policy implications for the government conducting both financial development and trade openness strategies to promote economic growth in China.

Table 4. ARDL Granger-causality analysis.

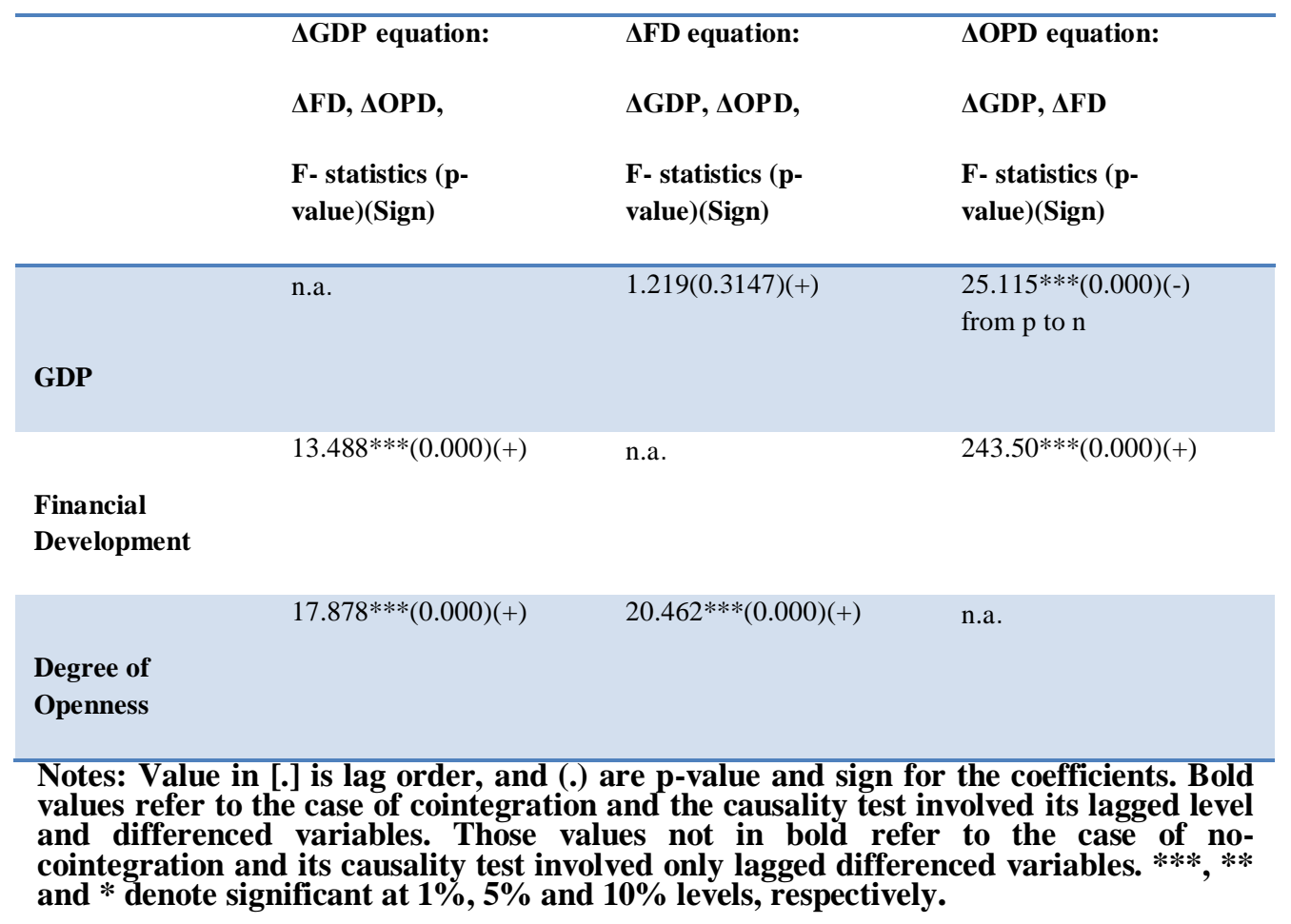


Revisit Financial Development, Trade Openness and Economic Growth Nexus in China Using a New Developed Bootstrap ARDL Test

\section{Conclusions}

In this study we attempt to investigate the impact of financial development and trade openness on economic growth (or GDP) in China using a newly developed Bootstrap ARDL model over the period of 1978-2015. Empirical results indicate no long-run relationship among these three variables and Granger causality test based on Bootstrap ARDL model indicates a feedback between GDP and trade openness and between financial development and trade openness and a one-way Granger causality running from financial development to economic growth in China (or GDP). By looking at the sign of coefficients of the independent variable that we find both financial development and trade openness promote economic growth (or GDP) in China. Financial development and trade openness reinforce each other. On the other hand, economic growth (or GDP) reduces trade openness. These empirical results have important policy implications for the government conducting both financial development and trade openness strategies to promote economic growth in China and financial development strategy is the most important one. Apparently our results support both the supplyleading and trade-leading hypothesis in China.

\section{REFERENCES}

[1]Barboza, G. A. \& Trejos, S. R. (2008), Empirical Evidence on Trade Reform, Revealed Trade Openness, and Output Growth in Latin America. How Far Have We Come?. Multinational Business Review, 16(4), 53-86;

[2]Beck, T. (2002), Financial Development and International Trade: Is there a Link?. Journalof International Economics. 57(1): 107-131;

[3]Chang, Tsangyao (2002), Financial Development and Economic Growth in Mainland China: A Note on Testing Demand Following or Supply-Leading Hypothesis; Applied Economics Letters, 9, 869-873;

[4]Chang, Tsangyao and Steven B. Caudill (2005), Financial Development and Economic Growth: The Case of Taiwan. Applied Economics 37, no. 12: 1329-1335; [5]Chen, Y. (2008), Opening-up or Institutional Development? Evidence from China. International Economic Journal. 22(4): 419-430;

[6]Hye, Q.M.A., Wizarat, S. and Lau, W. (2016), The Impact of Trade Openness on Economic Growth in China: An Empirical Analysis. Journal of Asian Finance, Economics and Business. 3:27-37;

[7]Kim, D. H., Lin, S. C. \& Suen, Y. B. (2012), The Simultaneous Evolution of Economic Growth, Financial Development, and Trade Openness. The Journal of International Trade \& Economic Development, 21(4), 513-537;

[8] Krugman, P. (1990), Policy Problems of a Monetary Union. The European monetary system in the 1990s, 48-64; 
[9]Kwiatkowski, D., Phillips, P., Schmidt, P. and Shin, Y. (1992), Testing the Null Hypothesis of Stationarity against the Alternative of a Unit Root: How Sure Are We that Economic Time Series Have a Unit Root? Journal of Econometrics, 54, 159-178; [10]Levine, Ross and Renalt, D. (1992), A Sensitivity Analysis of Cross-country Growth Regressions. American Economic Review. 82(4): 942-963;

[11]Mankiw, N. G., Romer, D. and Weil, D. N. (1992), A Contribution to the Empirics of Economic Growth. Quarterly Journal of Economics. 107: 407-437;

[12]Menyah, K., Nazliglu, S. and Wolde-Rufael, Y. (2014), Financial Development, Trade Openness and Economic Growth in African Countries: New Insights from a Panel Causality Approach; Economic Modelling, 37, 386-394;

[13]Ozdemir, D. (2014), Economic Growth and Financial Liberalization in EU Accession Countries. Applied Economic Letters. 21(15): 1036-1044;

[14]McNown, R., Sam, Chung Yan and Goh, Soo Khoon (2018), Bootstrapping the Autoregressive Distributed Lag Test for Cointegration; Applied Economics, 50:13, 15091521 ;

[15]Pesaran, M. H., Shin, Y. \& Smith, R. J. (2001), Bounds Testing Approaches to the Analysis of Level Relationships. Journal of applied econometrics, 16(3), 289-326; [16]Phillips, P. C. \& Perron, P. (1988), Testing for a Unit Root in Time Series Regression. Biometrika, 75(2), 335-346;

[17]Rehman, M.Z., Ali, N. and Nasir, N. M. (2015), Linkage between Financial Development, Trade Openness and Economic Growth: Evidence from Saudi Arabia. Journal of Applied Finance \& Banking, 5, 6, 127-141;

[18]Ricardo, D. (1817), Principles of Political Economy and Taxation. LondonL J. Murray;

[19]Robinson, J. (1952), The Rate of Interest and Other Essays. London: Macmillan; [20]Romilly, P., Song, H. and Liu, X. (2001), Car Ownership and Use in Britain: A Comparison of the Empirical Results of Alternative Cointegration Estimation Methods and Forecasts; Applied Economics, 33, 1803-1818;

[21]Sakyi, D., Villaverde, J. and Maza, A. (2015), Trade Openness, Income Levels, and Economic Growth: The Case of Developing Countries 1970-2009. The Journal of International Trade \& Economic Development. 24(6): 890-882;

[22]Saaed, A. A. B. and Hussain, M. L (2015), The Causal Relationship among Trade Openness, Financial Development and Economic Growth: Evidence from Kuwait; Journal of Emerging Issues in Economics, Finance, and Banking, 4, 1, 1385-1413; [23]Shin, Yongcheol, Byungchul Yu, Matthew Greenwood-Nimmo (2014), Modelling Asymmetric Cointegration and Dynamic Multipliers in a Nonlinear ARDL Framework; Chapter 9;

[24]Smith, A. (1776), An Inquiry into the Nature and Causes of the Wealth of Nations. Dublin: Printed for Messrs. Whitestone [and 19 others];

[25]Srinivasan, T. N. \& Bhagwati, J. (2001), Outward-orientation and Development: Are Revisionists Right?. In Trade, development and political economy (pp. 3-26). Palgrave Macmillan, London;

[26]Zhang, L., Luo, M., Yang, D. and Li, K. (2017), Impact of Trade Liberalization on Chinese Economy with Belt and Road Initiative. Maritime Policy \& Management. 